\title{
Relation between basic coal seam parameters and their gas saturation for Dobrudzha coal field, NE Bulgaria
}

\author{
Nikolay Hristov ${ }^{1 *}$, Efrosima Zaneva-Dobranova ${ }^{1}$, Gergana Meracheva ${ }^{1}$, Viktoriia Dmytrenko ${ }^{2}$, and Yuriy Vynnykov ${ }^{2}$ \\ ${ }^{1}$ University of Mining and Geology «St. Ivan Rilski», Faculty of Geology and Exploration, 1 Prof. Boyan Kamenov Str., Sofia, Bulgaria \\ ${ }^{2}$ National University «Yuri Kondratyuk Poltava Polytechnic», Department of Oil and Gas Engineering and Technology, 24 \\ Pershotravneva Ave., Poltava, 36011, Ukraine
}

\begin{abstract}
One of the main natural gas contained in the coal seams is methane. Most of it is adsorbed on the surface of the coal matrix, another is in free state in different in size and morphology pore spaces or dissolved gas in the waters that associate with the coal seams. The form of presence and the degree of gas saturation depends on the rank of the carbonization process, the petrophysical and physicochemical parameters of the environment. Methane in coal seams is accepted to be categorized as an unconventional energy resource. From this point of view, it is of interest in the Dobrudzha coal basin, located in the North-eastern part of Bulgaria. The specific geological conditions of the basin, the limited study, the presence of a thick covering aquifer make it difficult to extract coal by traditional methods. This requires the use of non-popular for the country methods for energy extraction and establishing relation between the basic parameters of coal seams and their gas saturation. The existing geological-geophysical, drilling and laboratory information is combined in a detailed petrophysical model, which extends over the best presented and studied coal seam (m5) from the field. The basic parameters that reflect the amount of adsorbed gas and are the subject of study are the content of moisture, carbon, ash and the degree of carbonization, expressed by the vitrinite and its reflectance.
\end{abstract}

\section{Introduction}

Coal bed methane (CBM) is an integral part of the coal formation process. It is one of the main unconventional resources which became very important for the energy supply in last 20 years. CBM has attracted major attentions worldwide because it is considered as a potential clean source of energy in sustainable future [1]. Coalbed methane is different from conventional natural gas, mainly due to the predominant form of presence adsorbed on the matrix. A relatively small part of it is in a free, concentrated space of different size and morphology or gas dissolved in coal waters. The ratio between the forms of presence of the gas mixture largely depends on the amount of coal substance. Methane reaches $60-80 \%$ of the total gas content in coal [2-4].

In the catagenic transformation of coal from brown to black, the formed methane is in the range of 30-40 to 120$150 \mathrm{~m}^{3} / \mathrm{t}$, and in the transition from black to anthracite coal it reaches $200 \mathrm{~m}^{3} / \mathrm{t}$ [5]. The accumulated large amounts of methane are under significant pressure and as a result of many factors (geological structure of the basin, properties of the reservoir rocks, water in reservoirs, petrographic composition and coal rank) explosions, gas emissions, its expulsion into tectonic fractures or in adjacent porous rocks are possible. The adsorption capacity depends on the degree of carbonization. It improves upwards - from shiny, brown to black gas and semi-anthracite to super-anthracite [6]. At greater depths, however, the sorption capacity decreases, even with increasing pressure to values above $10 \mathrm{MPa}$. Coal seams have considerably different characteristics from normal gas reservoirs, especially in gas storage and permeability features. Most gas storage in coal is by sorption into the coal structure, while the permeability is mainly produced by cleat (fracture) or joint controlled. It is also evident that there is a wide variation in coalbed permeability during production phases due to stress effect, which increases with fluid pressure reduction and shrinkage of coal. Coal seams have been described by two main porosity systems including: cleats (uniformly distributed network of natural fractures) and matrix blocks. The cleat (fracture) system of coal seams is divided into the face cleat and the butt cleat [7]. The most important property of coal beds is the permeability, which is mainly created by natural fractures. Coal formation may shrink on desorption of gas and may expand again on resorption. During the primary production phase of methane, two main phenomena are identified to associate depletion of reservoir pressure causing reduction of coal permeability. These two phenomena include: (1) reservoir compaction, which causes an increase in the effective horizontal stress while the reservoir is confined laterally; and (2) gas (mainly methane) desorption from the coal matrix; it causes coal matrix to shrink, reduce horizontal stress, and increase cleat permeability. Economical coal bed methane production depends on four important coal-seam characteristics including gas pressure, gas content, coal-

\footnotetext{
* Corresponding author: nk.hristov@gmail.com
} 
seam thickness and permeability [8]. The knowledge of coal seams properties and behaviour are the key for successful production process and for increasing the produced volumes of natural gas.

\section{Geological settings}

Dobrudzha coal field is located in NE Bulgaria, within the eastern slope of the North Bulgarian High, which underwent three structural transformations, manifested with different intensity: through the Carboniferous - of weakly manifested placative and well-defined fault tectonics; in Perm - with a bright manifestation of block tectonics and in the Jurassic and Neogene - with weakly manifested block tectonics (fig 1). It covers area of approximately 200 sq.km. with significant proven coal reserves of about 2 billion tons [9]. Coals are with Carboniferous Age and the commercial reserves has been estimated in Upper Carboniferous Series. The field is nonmineable because of the existence of $900 \mathrm{~m}$ thick aquifer above. The field is covered by wells grid with dimensions of 500x500 m with average depth of well $-2000 \mathrm{~m}$. There is conducted 2D seismic survey in volume of $600 \mathrm{~km}$, but the presence of thick highly cavernous aquifer made the results poor and useless in intervals with Carboniferous Age. This is the main reason to investigate wellbore and log data during the drilling process.

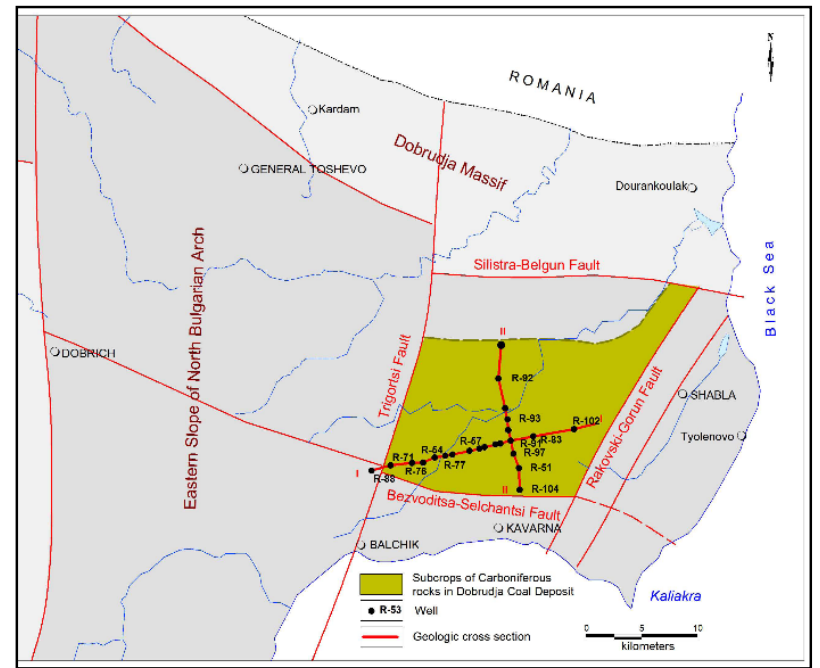

Fig. 1. Dobrudzha coal field location and location of some wells, used for the study.

The field is characterized with complicated geological settings, caused by several tectonic events with Triassic, Cretaceous and Eocene Ages. The major tectonic event, forming the nowadays view of the field is this one with Triassic Age. There are two type of faults in the field buried one, related to Carboniferous Age and covered by Lower Triassic sediments and younger one, and faults affecting whole sedimental section. The filed is divided by fault to 28 separated areas (blocks) with different coal seam properties. All of the faults have been located using drilling data, because of the poor seismic quality in the area. Fault geometry and influence radius has been investigated using drilling and logging data. Every wellbore in the field have standard for its time logging data such are Calliper, Deviation surveys, Electrical methods (shallow and deep lateral log), Neutron gamma ray, Gamma ray and Density log. With consideration of made lithological and stratigraphical division and correlation of the formation of Upper Carboniferous, the division made before is being confirmed later [10], which is with clearly separation of four main coal formation arranged geochronological as follows: Mogilishte, Macedonka, Krupen and Gurkovo (fig. 2).

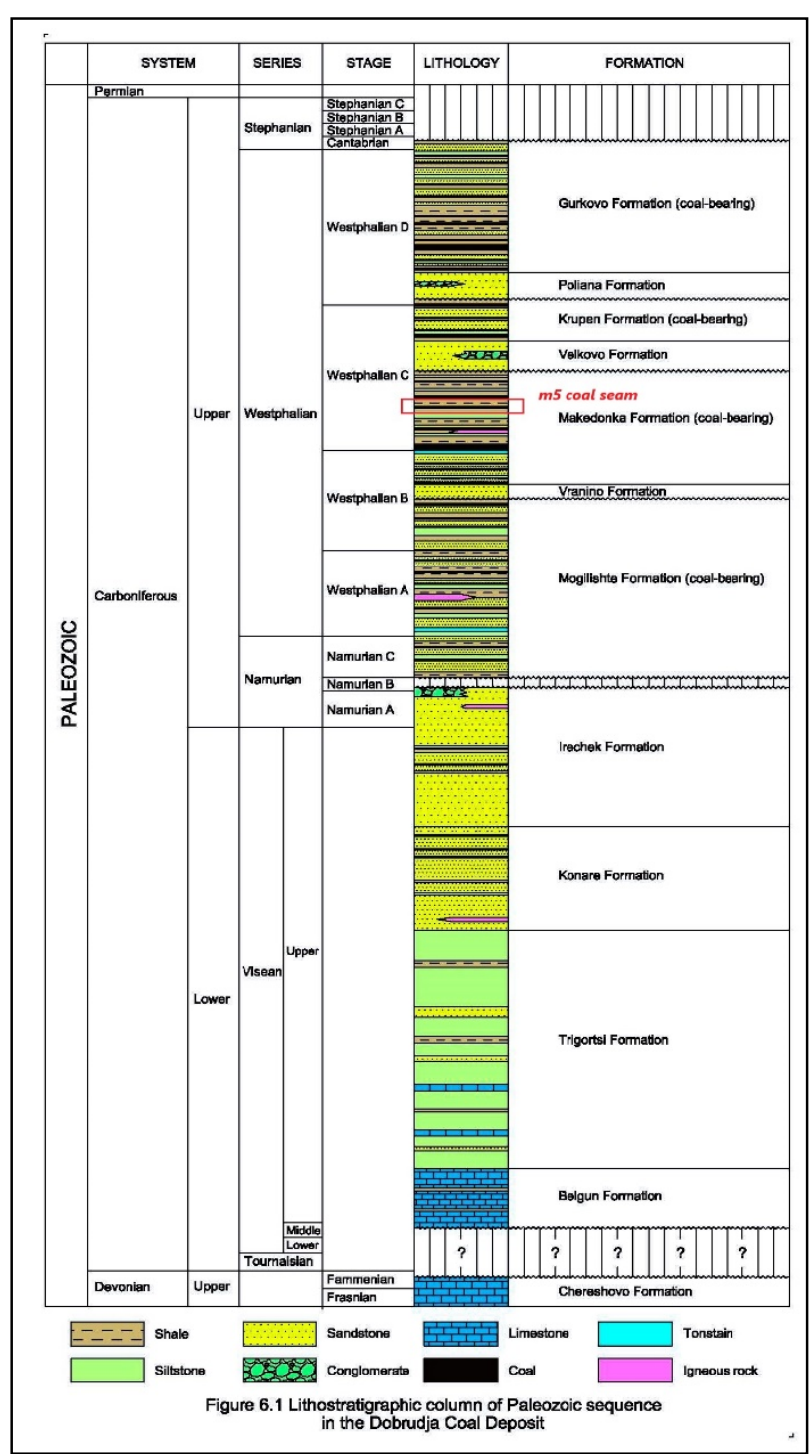

Fig. 2. Litho-stratigraphy of the Carboniferous System of Dobrogea coal field.

The Upper Carboniferous field contain a total of over 86 coal seams, of which 16 are of industrial importance. Coal is black from all classes to anthracite in most of the formations. The rocks containing them are relatively uniform in lithological composition with predominant terrigenous (sandstones, siltstones, argillites, in some places gravelites) lithotypes - products of lake-swamp sedimentation. The total thickness of the coal field exceeds $1300 \mathrm{~m}$. This new updated lithostratigraphic correlation, formations boundaries identification and updated correlation of coal seams from the Upper 
Carboniferous section [10] is establish by using modern software products and available above-mentioned log records for most of the wells. For identification of coal seams data from core, log records and laboratory analysis of samples in the field are used.

\section{Materials and methods}

Finding the actual gas content in coal seams can be done directly - in the laboratory, or indirectly. The direct method of determining sorption isotherms involves drilling and cutting core that is immediately placed in canisters, followed by measurements of the volume of gas evolved from the coal over time.

The basic coal seam properties, which are chosen to investigate their relation to the gas saturation are as follows:

- Moisture - Moisture is an important property of coal and its presence and quantity are directly related to the processes of carbonization and subsequent transformation of sediments. Groundwater and other extraneous moisture are known as adventitious moisture and is readily evaporated. Moisture held within the coal itself is known as inherent moisture and is analysed quantitatively. Adventitious moisture is removed in the laboratory by evaporation in air. Moisture may occur in four possible forms within coal: surface moisture: water held on the surface of coal particles or macerals; hydroscopic moisture: water held by capillary action within the microfractures of the coal; decomposition moisture: water held within the coal's decomposed organic compounds; mineral moisture: water which comprises part of the crystal structure of hydrous silicates such as clays. Moisture content in a coal decreases the sorption capacity. Because coal loses moisture at a variable rate subsequent to removal from the borehole, a standard moisture content is used when measuring sorption isotherms.

- Fixed carbon content of the coal is the carbon found in the material which is left after volatile materials are driven off. This differs from the ultimate carbon content of the coal because some carbon is lost in hydrocarbons with the volatiles. Fixed carbon is used as an estimate of the coke yield from a sample of coal. Fixed carbon is determined by subtracting the mass of volatiles, determined above, from the original mass of the coal sample.

- Ash content of coal is the non-combustible residue left after coal is burnt. It represents the bulk mineral matter after carbon, oxygen, sulphur and water (including from clays) has been driven off during combustion. Analysis is fairly straightforward, with the coal thoroughly burnt and the ash material expressed as a percentage of the original weight. The lower ash content is indicator for more gas content.

- Vitrinite is the most common component of coal. It is also abundant in kerogen, derived from the same biogenic precursors as coals, namely land plants and humic peats. Vitrinite forms diagenetically by the thermal alteration of lignin and cellulose in plant cell walls. It is therefore common in sedimentary rocks that are rich in organic matter, such as shales and marls with a terrigenous origin. Conversely, carbonates, evaporites, and well-sorted sandstones have very low vitrinite content. Vitrinite is absent in pre-Silurian rocks because land plants had not yet evolved.

- Vitrinite reflectance was first studied by coal geologists attempting to determine the thermal maturity, or rank, of coal beds. More recently, it is used to study sedimentary organic matter from kerogen. It is sensitive to temperature ranges that correspond to hydrocarbon generation $\left(60\right.$ to $\left.120^{\circ} \mathrm{C}\right)$. This means that, with a suitable calibration, vitrinite reflectance can be used as an indicator of maturity in hydrocarbon source rocks. Generally, the onset of oil generation is correlated with a reflectance of 0.5 to $0.6 \%$ and the termination of oil generation with reflectance of 0.85 to $1.1 \%$

All of the performed logging data was used for coal seams properties estimations applying modern software and approaches. During the drilling process, all wells were cored for all carboniferous section. There is available multiple laboratory test of the core focused on measurements of coal seam properties such as moisture, ash content, Sulphur content, violates. Some core samples were measured for gas content, but their number is very limited. The poor knowledge of coal seam gas content requires performing multiple investigations on $\log$ data and calculations based on the laboratory measurements. A number of petrophysical tests have been performed to establish and prove the results obtained synthetically from the available logging data with these laboratory tests. The information is entered into tables and converted into specialized digital formats, which are loaded into software products for geological modelling and interpretation.

\section{Result and discussion}

After loading the data and their implementation in the already created geological, tectonic and hydrogeological models [11], maps of the distribution of the various parameters by area within the locality for each layer were made. Several coal seams are suitable for gas extraction those one with abbreviation $m 5, m 6, m 9, n 1, n 4, p 3$ located in above mentioned formations. The current investigation is focused on $\boldsymbol{m} \mathbf{5}$ coal seam (Fig. 3.) buried on depth interval $1300-1900 \mathrm{~m}$ in Makedonka formation.

The minimum depths are in the easternmost parts of the locality, and in most of its area of distribution the depth of occurrence is over $1600 \mathrm{~m}$ (Fig.4). The average thickness of coal seam is about $5 \mathrm{~m}$, but in the field, there is places where its thickness reaches $13 \mathrm{~m}$. Coal seam $\mathbf{m 5}$ is with one of the largest thickness in the field. In the wells in the western and central parts of the field there is a complex structure of the layer - from 2 to 10 layers. The reason for choosing this coal seam is that it is low interbedded, with a large area distribution and a relatively large thickness and has average gas content from 18 to 28 $\mathrm{m}^{3} / \mathrm{t}$ of hard coal [12]. 


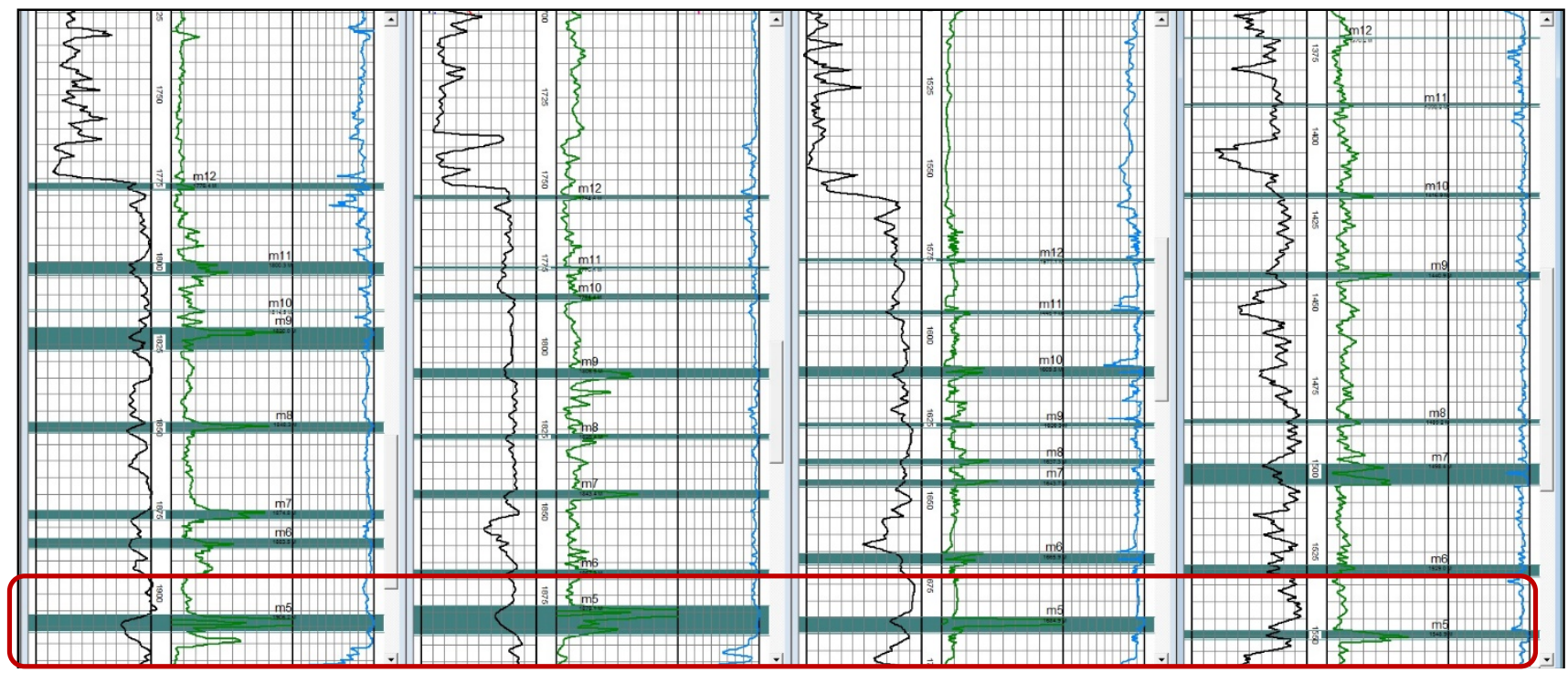

Fig. 3. Correlation scheme of $\mathrm{m} 5$ coal seam.

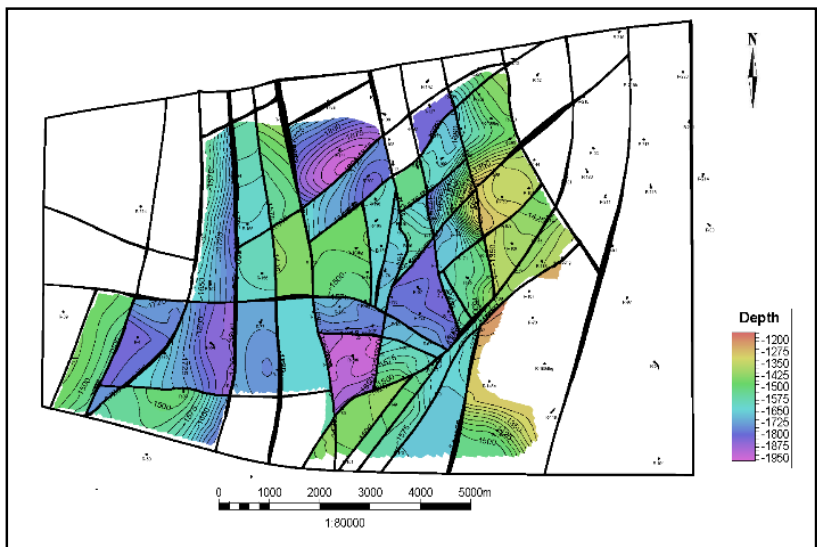

Fig. 4. Depth map of m5 coal seam.

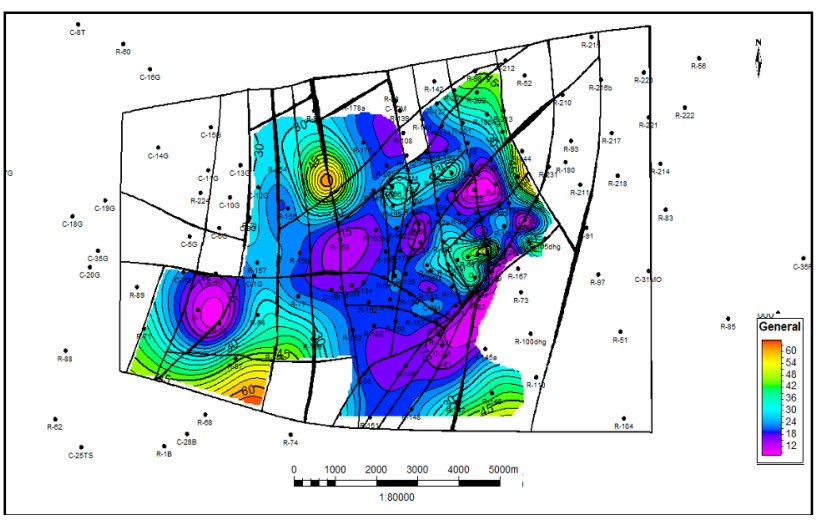

Fig. 5. Ash content (\%) map of m5 coal seam.

Using the result of the laboratory tests detailed petrophysical model of the formation which includes $\boldsymbol{m} \mathbf{5}$ coal seam was created. The average ash content is not very high, but its values in different parts of the field vary widely. The ash is unevenly distributed over the area of the layer, as the minimum values are in the central parts of the field. The results are showing higher ash content in coal field edges and low ash content in the middle of the field (Fig. 5). Using data from the investigation it can be conclude that the most suitable part for coal bed methane extraction is the central part of the field. The results from some laboratory test shows $28 \mathrm{~m}^{3} / \mathrm{t}$ gas content for this particular area.

The moisture content of the coal varies widely. There is a tendency to decrease the value of this indicator from northwest to southeast. (Fig. 6).

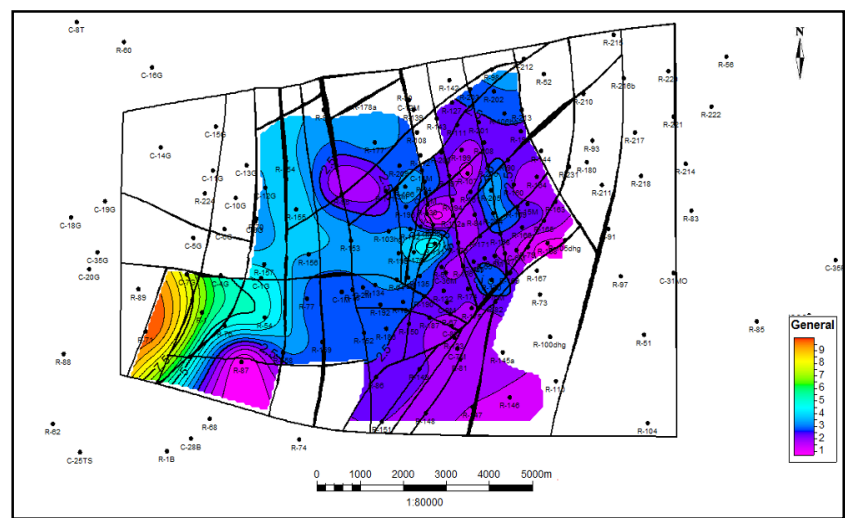

Fig. 6. Moisture content (\%) map of m5 coal seam.

The gas content of layer $\boldsymbol{m} \mathbf{5}$ varies in a very wide range, which depends on the depth of formation in different parts of the field. At shallower depths (up to $1600 \mathrm{~m}$ ) the gas content is the lowest and the composition of the gases is dominated by nitrogen. The layer with the highest gas content is characterized in the range of depth from 1700 to $1800 \mathrm{~m}$, which outlines the so-called methane zone. The composition of the gases is dominated by methane [9]. As the depth of deposition increases, the gas content of the formation decreases, and in the gas phase the amount of methane decreases at the expense of increasing the hydrogen content, especially at depths above $1900 \mathrm{~m}$ (Table 1).

Based on the analyses and petrophysical modelling, it can be said that layer $\boldsymbol{m} \mathbf{5}$ is one of the main layers in the Dobrudzha coal field, which are extremely suitable for $\mathrm{CBM}$ in almost all key indicators - area and distribution; layer thickness; amount of resources; degree of

\footnotetext{
* Corresponding author: nk.hristov@gmail.com
} 
carbonization; high yield of volatile substances, moisture; relatively low ash content, petrographic composition dominated by vitrinite macerals, with a significant amount of inertinite; low sulphur content, high gas content and methane content, especially in some parts of the field, low density and relatively high porosity (Table 2 ).

Table 1. Composition and volume of the gas components distributed in depth in $\boldsymbol{m 5}$ coal seam.

\begin{tabular}{|l|c|c|c|c|c|c|c|c|c|}
\hline Depth, $\mathbf{m}$ & \multicolumn{7}{|c|}{ Gas component composition, \% } & \multicolumn{2}{c|}{ Gas component volume, $\mathbf{c m}^{\mathbf{3}}$} \\
\hline & $\mathbf{H}_{\mathbf{2}}$ & $\mathbf{N}_{\mathbf{2}}$ & $\mathbf{C O}_{\mathbf{2}}$ & $\mathbf{C H}_{\mathbf{4}}$ & $\begin{array}{l}\mathbf{C}_{\mathbf{2}} \mathbf{H} \\
\mathbf{6}\end{array}$ & $\begin{array}{l}\mathbf{C}_{\mathbf{3}} \mathbf{H} \\
\mathbf{8}\end{array}$ & $\mathbf{C}_{\mathbf{n}} \mathbf{H}_{\mathbf{2} \mathbf{+}+\mathbf{2}}$ & $\mathbf{C}_{\mathbf{n}} \mathbf{H}_{\mathbf{2} \mathbf{+}}$ & Total gas content \\
\hline $1400-1600$ & - & 99.5 & 0.1 & 0.1 & - & - & 0.1 & 0.02 & 23.0 \\
\hline $1600-1700$ & - & - & - & - & - & - & - & - & - \\
\hline $1700-1800$ & 1.6 & 9.4 & 3.9 & 84.6 & 0.3 & 0.2 & 85.1 & 5263 & 6167.5 \\
\hline $1800-1900$ & 0.6 & 28.5 & 4.3 & 66.1 & 0.3 & 0.1 & 66.5 & 2277 & 3070 \\
\hline $1900-2000$ & 63.85 & 13.6 & 1.1 & 20.2 & 0.9 & 0.4 & 21.5 & 738 & 3919 \\
\hline
\end{tabular}

Table 2. Basic $\boldsymbol{m} 5$ coal seam parameters.

\begin{tabular}{|c|c|c|c|c|c|}
\hline \multirow{2}{*}{\multicolumn{2}{|c|}{ Parameters }} & \multirow[t]{2}{*}{ Unit } & \multicolumn{3}{|c|}{ Value } \\
\hline & & & Min & Max & Average \\
\hline \multicolumn{2}{|c|}{ Area of distribution } & $\mathrm{km}^{2}$ & \multicolumn{3}{|c|}{57.0} \\
\hline \multicolumn{2}{|c|}{ Depth } & $\mathrm{m}$ & 1288 & 1906 & 1746.00 \\
\hline \multicolumn{2}{|l|}{ Thickness } & $\mathrm{m}$ & 1.70 & 12.90 & 4.80 \\
\hline \multicolumn{2}{|l|}{ Moisture, $\mathrm{W}^{\mathrm{a}}$} & $\%$ & 1.0 & 4.6 & 2.82 \\
\hline \multicolumn{2}{|l|}{ Ash content, $\mathrm{A}^{\mathrm{d}}$} & $\%$ & 7.5 & 54.0 & 25.05 \\
\hline \multicolumn{2}{|c|}{ Yields of volatile substances, $\mathrm{V}^{\text {daf }}$} & $\%$ & 30.3 & 42.1 & 37.08 \\
\hline \multirow{3}{*}{ Composition } & Vitrinite & $\%$ & & & 60 \\
\hline & Exinite & $\%$ & & & 15 \\
\hline & Inertite & $\%$ & & & 25 \\
\hline \multicolumn{2}{|l|}{ Mineral impurities } & $\%$ & & & 10 \\
\hline \multicolumn{2}{|c|}{ Vitrinite reflectance, $r_{o}$} & $\%$ & 0.71 & 1.10 & \\
\hline \multicolumn{2}{|c|}{ Bound carbon content, C (ar)* } & $\%$ & 32.06 & 58.45 & 43.91 \\
\hline \multirow{2}{*}{$\begin{array}{l}\text { Gas components } \\
\text { volume }\end{array}$} & Total gas content & $\mathrm{cm}^{3}$ & 23.0 & 6551.8 & \\
\hline & $\mathrm{C}_{\mathrm{n}} \mathrm{H}_{2 \mathrm{n}+2}$ & $\mathrm{~cm}^{3}$ & 0.02 & 5815.2 & \\
\hline \multirow{8}{*}{$\begin{array}{l}\text { Gas component } \\
\text { composition }\end{array}$} & $\mathrm{He}$ & $\%$ & 0.0 & 0.3 & \\
\hline & $\mathrm{H}_{2}$ & $\%$ & 0.0 & 83.2 & \\
\hline & $\mathrm{N}_{2}$ & $\%$ & 6.1 & 99.5 & \\
\hline & $\mathrm{CO}_{2}$ & $\%$ & 0.1 & 7.2 & \\
\hline & $\mathrm{CH}_{4}$ & $\%$ & 0.1 & 88.2 & \\
\hline & $\mathrm{C}_{2} \mathrm{H}_{6}$ & $\%$ & 0.0 & 1.3 & \\
\hline & $\mathrm{C}_{3} \mathrm{H}_{8}$ & $\%$ & 0.0 & 0.6 & \\
\hline & Total $\mathrm{C}_{\mathrm{n}} \mathrm{H}_{2 \mathrm{n}+2}$ & $\%$ & 0.1 & 88.8 & \\
\hline \multicolumn{2}{|l|}{ Bulk density } & $\mathrm{g} / \mathrm{cm}^{3}$ & 1.28 & 2.53 & 1.49 \\
\hline \multirow{2}{*}{ Porosity } & Total & $\%$ & 4.00 & 16.10 & 10.02 \\
\hline & effective & $\%$ & 1.55 & 10.45 & 4.81 \\
\hline
\end{tabular}

\section{Conclusions}

Based on the research conducted on the relationship between basic coal seam parameters and gas saturation, it follows that:

- A direct relationship between the studied parameters and the gas saturation of the coal exists;

- A relationship between faults and the distribution of moisture content, ash content and the degree of variation in vitrinite reflectance is observed;

- According to its main indicators, coal seam $\mathbf{m 5}$ is suitable for application of CBM technology for methane gas extraction;

- The demonstrated approach finds application for clarification of the interdependence between the studied parameters for the other layers as wells.

\section{References}

1. A. J. Ahmed, S. Johnston, C. Boyer, S.W. Lambert, O.A. Bustos, J.C. Pashin, and A. Wray, Coalbed methane: Clean energy for the world, Oilfield Review, 4-16 (2009)

2. Ch. Clarkson, R. M. Bustin, Coalbed Methane: Current Field-Based Evaluation Methods, SPE 14, 60-75, (2011). https://doi.org/10.2118/131791-PA

3. V. Vishal, L. Singh, S.P. Pradhan, T.N. Singh, P.G. Ranjith, Analog modeling of Gondwana coal seams in India as coalbed methane reservoirs substituted for carbon dioxide sequestration, Energy 49, 384-394. (2013a).

4. J.C. Pashin, M.R. McIntyre, R.E. Carroll, R.H. Groshong Jr., R.M. Bustin, Carbon sequestration and enhanced recovery potential of mature coalbed 
methane reservoirs in the Black Warrior Basin. Am. Assoc. Petrol. Geol. Stud. Geol. 59, 125-147, (2009). doi:10.1306/13171237St592825

5. A.I. Kravtsov, Fundamentals of geology of combustible minerals. M. Higher School, 424 (1982).

6. J.R. Levine, Coallification the evulation of coal as a source rock for oil and gas. In Law B.E. \&Rise, d.d. (eds): Hydrocarbons from Coal, Amer.Assoc. Petrol. Geol. Stud. In Geol. Ser., 38 (1993).

7. Q. Shi, and S. Durucan, A Model for Changes in Coalbed Permeability During Primary and Enhanced Methane Recovery, SPE, 8, 291 - 299, (2005). https://doi.org/10.2118/87230-PA

8. C.R. McKee, A.C. Bumb, R.A. Koenig, Stress dependent permeability and porosity of coal and other geologic formations. Soc. Petrol. Eng. Formation Evaluation, March 1988, 81-91, (1988).

9. Z. Nikolov, E. Stefanova, J. Tenchov, K. Popova, A. Popov, T. Dimitrova, G. Manev, V. Parashkevova, I. Ivanov, J. Yanakiev, R. Peeva, Geology of the Dobrudzha coal basin. S., Technika, 170 (1988).

10. N. Hristov, D. Merachev, J. Kortenski, D. Bukolska, M. Green. Study of deep lying coals of the Dobrudzha Coal Deposit in Bulgaria for underground coal gasification and the permanent storage of $\mathrm{CO} 2$ in the affected areas. Int. J. of 23rd IMCE Turkey, 248-251, (2013).

11. N. Nakaten, T. Kempka, M. Green, A. Preshelkova, D. Merachev, R. Schlüter, and R. Azzam. Development of a technical-economic model for dynamic calculation of COE, energy demand and $\mathrm{CO} 2$ emissions of an integrated UCG-CCS process, EGU General Assembly 2012, held 22-27 April, 2012 in Vienna, Austria, p. 1781. (2012).

12. L. Gerov, L. Georgiev. Evaluation of the methods for research of the sorption processes in coal seams. Annual UMG "St. Ivan Rilski”, 52, 1, 145-148, (2009). 